8834-2019-3-106-109

3. Boozaya-Angoon D., Starks K.J., Edwards L.H., Pass H. Inheritance of resistance in oats to two biotypes of the greenbug // Environm. Entomol. - 1981. - V . 10. - № 4. - P. 557-559. DOI: 10.1093/ee/10.4.557

4. Gardenhire J.H. Inheritance of greenbug resistance in oats // Crop Sci. - 1964. V. 4. - № 4. - P. 443. DOI:10.2135/cropsci1964.0011183X000400040041x

5. Harvey T.L., Kofoid K.D., Martin T.J., Sloderbeck P.E. A new greenbug virulent to E-biotype resistant sorghum // Crop Sci. - 1991. - V. 31. - № 6. - P. 1689-1691. DOI: 10.2135/cropsci1991.0011183X003100060062x

6. Kindler S.D., Spomer S.M. Biotypic status of six greenbug (Homoptera: Aphididae) isolates // Environ. Entomol. - 1986. - V. 15. - № 3. - P. 567-572. DOI: 10.1093/ee/15.3.567

7. Puterka G.J., Peters D.C., Kerns D.L., Slosser J.E., Bush L., Worrall D.W., McNew R.W. Designation of two new greenbug (Homoptera: Aphididae) biotypes G and H // J. Econ. Entomol. - 1988. - V. 81. - № 6. - P. 1754-1759. DOI: 10.1093/jee/81.6.1754

8. Radchenko E.E., Kuznetsova T.L., Chumakov M.A., Loskutov I.G. Greenbug (Schizaphis graminum) resistance in oat (Avena spp.) landraces from Asia // Genetic Res. Crop Evol. - 2018. - V. 65. - № 2. - P. 571-576. DOI: 10.1007/s10722-017-0554-9

9. Starks K.J., Burton R.L., Merkle O.G. Greenbugs (Homoptera: Aphididae) plant resistance in small grains and sorghum to biotype E // J. Econ. Entomol. - 1983. - V. 76. № 4. - P. 877-880. DOI: 10.1093/jee/76.4.877

\title{
Разнообразие генофонда дикорастущих видов секции Petota Dumort. рода Solanum L. для современной селекции картофеля
}

Рогозина Е.В. *1, Чалая Н.A. ${ }^{1}$, Кузнеияова M.A. ${ }^{2}$, Бекетова М.П. ${ }^{3}$, Хавкин Э.Е. ${ }^{3}$

${ }^{1}$ Федеральный исследовательский центр Всероссийский институт генетических ресурсов растений им. Н.И. Вавилова (ВИР), Санкт-Петербург, Россия,

${ }^{2}$ Всероссийский научно-исследовательский институт фитопатологии, Московская область, Б. Вяземы, Россия,

3 Всероссийский научно-исследовательский институт сельскохозяйственной биотехнологии, Москва, Россия.

*e-mail: erogozina@vir.nw.ru

В коллекции ВИР выделены образцы диких клубнеобразующих видов Sоlaпuт L. и межвидовых гибридов - источники устойчивости картофеля к фиmофторозу (Phytophthora infestans (Mont.) de Bary), Y вирусу картофеля (YВK), золотистой картофельной нематоде nатотипа Rol (Globodera rostochiensis (Wollenweber) Behrens). Методом ПЦР с помощью ДНКммаркеров генов R1, R3a, R3b, RB/Rpi-blb1, Rpi-vnt1, Rysto, Ryadg, Rychc, H1, Gro1-4 проведен скрининг этой коллекции генотипов картофеля. Структурные гомологи генов устойчи- 
вости обнаружены у широкого круга дикорастущих родичей картофеля. Выявлены клоны межвидовых гибридов, перспективные для использования в селекчии, в том числе с использованием технологии маркер-опосредованного отбора.

Ключевые слова: R гены, фитофтороз, Y вирус картофеля, золотистая нематоде, ДНК маркеры.

\title{
Diversity of genepool of wild solanum species (section Petota Dumort.) currently employed in potato breeding
}

\author{
E.V. Rogozina ${ }^{1}$, N.A. Chalayal, M.A. Kuznetsova ${ }^{2}$, M.P. Beketova ${ }^{3}$, E. Khavkin ${ }^{3}$ \\ ${ }^{1}$ N.I. Vavilov All-Russian Institute of Plant Genetic Resources (VIR), St. Peters- \\ burg, Russia, \\ ${ }^{2}$ All-Russia Research Institute of Phytopathology, Moscow Province, Russia, \\ ${ }^{3}$ All-Russian Research Institute of Agricultural Biotechnology, Moscow, Russia. \\ e-mail:erogozina@vir.nw.ru
}

Numerous accessions of wild tuber-bearing Solanum L. species and interspecific potato hybrids maintained in VIR collection manifest wide diversity of potato germplasm prospective as the sources of resistance to late blight (the causal agent Phytophthora infestans (Mont.) De Bary), Y potato virus (YBK) and golden potato nematode. PCR screening with PCR using DNA markers for the R1, R3a, R3b, RB / Rpi-blb1, Rpi-vnt1, Rysto, Ryadg, Rychc, H1, Grol-4 genes has revealed the structural homologues of resistance genes in a wide range of wild potato relatives. The highlighted clones of interspecific hybrids are hopeful for deploying in current breeding based on the marker-assisted selection.

Key words: R-genes, late blight, Y-potato virus, golden nematode, DNA markers.

Картофелеводство принадлежит к ведущим отраслям сельского хозяйства Российской Федерации. Одним из основных факторов экологически чистого производства картофеля является возделывание сортов, устойчивых к вредоносным организмам, что позволяет минимизировать применение химических средств защиты. Для современной селекции картофеля в России весьма актуально создание новых сортов, обладающих комплексом желаемых хозяйственно ценных признаков, на основе сложных межвидовых гибридов, в родословной которых присутствуют сразу несколько дикорастущих видов картофеля - источники ценных генов $[1,2]$. Использование нового типа селекционных источников и доноров на основе сложных межвидовых гибридов с широким спектром устойчивости к болезням, в том числе к различным расам одного патогена, позволяет оперативно реагировать на быстрые изменения в составе популяций патогенов. Такой подход называют упреждающей селекцией $[3,4]$. 
Разнообразие генофонда дикорастущих сородичей картофеля - видов секции Petota Dumort. рода Solanum L. представляет широкий спектр отсутствующих у культурного картофеля признаков устойчивости к болезням и вредителям. В сравнении с другими сельскохозяйственными культурами, картофель располагает наибольшим разнообразием дикорастущих сородичей, по разным оценкам от 110 [5] до 196 видов [6], в коллекции ВИР представлено более 100 дикорастущих видов картофеля. Перспективы использования дикорастущих клубненосных Solanum spp. в селекции во многом определяются их совместимостью с культурным картофелем при скрещивании и характером наследования целевых признаков. Молекулярно-генетическая характеристика целевых генов у дикорастущих видов и межвидовых гибридов картофеля и создание на основе этих генов маркеров целевых признаков позволит значительно ускорить процесс их переноса от дикорастущих сородичей в культурный картофель.

Источники устойчивости к возбудителям экономически значимых болезней картофеля выделены среди образцов дикорастущих клубненосных Solanum spp. и межвидовых гибридов в коллекции ВИР, сохраняются в виде клонов в полевом генбанке ВИР (Санкт-Петербург, Пушкин). Впервые в мировой практике нами проведены координированные фитопатологические исследования и ДНК анализ клоновых растений, представляющих разнообразие генофонда видов секции Petota Dumort. рода Solanum L. B этой работе использованы ДНК-маркеры генов устойчивости к фитофторозу (Phytophthora infestans (Mont.) de Bary) (Rpi - Resistance to P. infestans - генов) $R 1, R 3 a, R 3 b, R B / R p i-b l b 1, R p i-b l b 2, R p i$-vnt 1 , генов устойчивости к Ү вирусу картофеля (YBK) $R y_{s t o}, R y_{a d g}, R y_{c h c} u$ генов устойчивости к золотистой картофельной нематоде патотипа Ro1 (Globodera rostochiensis (Wollenweber) Behrens). H1, Grol-4. Идентифицированы образцы диких видов и межвидовые гибриды картофеля, устойчивые к возбудителям этих болезней и несущие ДНК маркеры генов устойчивости, в том числе генов, различающихся по специфичности к расам патогена.

Обнаружены различия в распространении и частоте встречаемости ДНК маркеров Rpi генов у представителей клубненосных Solanum spp. SCAR маркеры Rpi генов выявлены у широкого круга дикорастущих видов, представляющих мексиканский и андийский центры происхождения культурных растений. У растений североамериканских видов серий Bulbocastana $(S$. bulbocastanum Dun.), Cardiophylla (S. cardiophyllum Lindl.), Demissa (S. brachycarpum Corr., S.hougasii Corr.), Longipedicellata (S. stoloniferum Schlechtd.) обнаружены маркеры генов $R 1, R 3 a, R 3 b, R B / R p i-b l b 1$. У южноамериканских видов серий Simpliciora ( $S$. simplicifolium Bitt.) и Tarijensia (S. berthaultii Hawkes) также обнаружены маркеры генов $R 1, R 3 a$. Структурные гомологи генов Rpi-blb2 u Rpi-vntl обнаружены у представителей южноамериканских видов S. alandiae Card. и S. okadae Hawkes et Hjerting [7]. 
Менее распространены в клоновой коллекции диких видов картофеля источники устойчивости к ҮВК. Образцы с экстремальной устойчивостью и сочетанием маркеров YES3-3A + YES3-3В гена $R y_{s t o}$ выявлены среди образцов $S$. stoloniferum и близкородственных (той же серии Longipedicellata) видов $S$. polytrichon Rydb. и S. papita Rydb., а также у вида S.cardiophyllum. У одного клона $S$. stoloniferum обнаружена комбинация маркеров RYSC3+RYSC4 гена $R y_{a d g}$. Скрининг 170 генотипов $S$. chacoense Bitt., контрастных по реакции на инфицирование YBK, выявил маркер Ry186 гена $R y_{\text {chc }}$ лишь у единичных генотипов, при этом присутствие маркера не было связано с признаком устойчивости.

У нематодоустойчивых образцов южноамериканских диких видов картофеля серий Tuberosa (S. alandiae, $S$. × doddsii Corr., S. famatinae Bitt., $S$. kurtzianum Bitt. et Wittm., S. leptophyes Bitt., S. sparsipilum (Bitt) Juz. et Buk.) и Yungasensia (S. yungasense Hawkes) обнаружен маркер Gro1-4-1 гена Gro14. Маркер TG689, ассоциированный с геном H1 и распространённый у сортов картофеля российской селекции [8], у нематодоустойчивых образцов диких видов отсутствовал.

Особый интерес для практической селекции представляют межвидовые гибриды картофеля, с групповой устойчивостью к болезням, у которых выявлены ДНК маркеры соответствующих Rpi генов. Более 60 клонов межвидовых гибридов с комплексом хозяйственно ценных признаков, устойчивые к фитофторозу, YВК и золотистой картофельной нематоде и несущие ДНК маркеры $R p i$ генов, генов $R y_{s t o}$ и $R y_{a d g}$, а также гена $H 1$, рекомендованы как родительские формы для создания конкурентоспособных отечественных сортов картофеля [9].

Благодарности: Работа поддержана грантом РФФИ № 18-016-00138.

\section{Список литературы}

1. Рогозина Е.В., Хавкин Э.Е. Межвидовые гибриды картофеля как доноры долговременной устойчивости к патогенам. Вавиловский журнал генетики и селекции. 2017. 21(1): 30-41. DOI 10.18699/VJ17.221

2. Симаков Е. А. и др. Использование генетических ресурсов картофеля для повышения эффективности селекции. Труды по прикл. бот., ген. и сел. 2017. 177(2):113-121.

3. Фадина О.А. и др. Упреждающая селекция: использование молекулярных маркеров при создании доноров устойчивости картофеля (Solanum tuberosum L.) к фитофторозу на основе сложных межвидовых гибридов. Сельскохозяйственная биология. 2017.52(1):84-94.

4. McIntosh, R.A., Brown, G.N. Anticipatory breeding for resistance to rust diseases in wheat. Annu. Rev. Phytol. 1997. 35:311-326. doi: 10.1146/annurev.phyto.35.1.311

5. Spooner D., Salas A. Structure, biosystematics and genetic resources. Handbook of Potato, Production, Improvement and Postharvest Management. Eds. J. Gopal, S.M.P. Khurana. N.Y.: Haworth Press, 2006;1-39. 
6. Hijmans R.J. et al., 2002. Atlas of Wild Potatoes. IPGRI, Rome.

7. Muratova (Fadina) O.A. et al. South American species Solanum alandiae Card. and S.okadae Hawkes et Hjerting as potential sources of genes for potato late blight resistance. Труды по прикл. бот., ген. и сел. 2020. 181(1):73-83.

8. Клименко Н.С. и др. Маркер-опосредованная селекция отечественных сортов картофеля с маркерами генов устойчивости к золотистой картофельной нематоде (патотип Ro1). Труды по прикл. бот., ген. и сел. 2017. 178(4): 66-75.

9. Рогозина Е.В. и др. Каталог мировой коллекции картофеля ВИР. Картофель. Межвидовые гибриды картофеля устойчивые к возбудителям болезней. Вып. 833. СПб. ВИР. 2018.

DOI 10.18699/GPB2020-63

\section{Разработка маркеров, контролирующих устойчивость ярового ячменя к патогену Cochliobolus sativus, на основе ассоциативного картирования}

Розанова И.В. ${ }^{1,3 *}$, Лашина H.M. ${ }^{2}$, Ефимов B.M. ${ }^{3}$, Афанасенко O.C. ${ }^{2}$, Хлесткина E.K. ${ }^{1,3}$

${ }^{1}$ Федеральный исследовательский центр Всероссийский институт генетических ресурсов растений им. Н.И. Вавилова (ВИР), Санкт-Петербург, Россия;

${ }^{2}$ Всероссийский научно-исследовательский институт защчитьл растений, Санкт-Петербург, Россия;

${ }^{3}$ Федеральный исследовательский центр институт циттологии и генетики СО РАН, Новосибирск, Россия.

*e-mail:bykova@bionet.nsc.ru

Несовершенный гриб, патоген Cochliobolus sativus - (Bipolaris sorokiniana (anamorph) (Sacc) Shoemaker) это один из наиболее широко распространенных патогенов, вызывающий различные болезни, в числе которых темно-бурая пятнистость и корневые гнили. Определение генетических локусов, ассоцичрованных с устойчивостью ячменя к этим болезням, важно для разработки диагностических ДНК-маркеров для селекции устойчивых сортов ячменя. Целью настоящей работы является выявление генетических локусов, ассоциированные с устойчивостью как проростков, так и взросльх растений ячменя к изолятам C. sativus на основе оценки Сибирской коллекции ярового ячменя.

Ключевые слова: Hordium vulgare, QTL, Cochliobolus sativus.

The marker development that controlling the resistance of spring barley to Cochliobolus sativus pathogen using association mapping approach

Rozanova I.V. ${ }^{* 1,2}$, Lashina N.M ${ }^{3}$, Efimov V.M. ${ }^{2}$ Afanasenko O.S. ${ }^{3}$, Khlestkina E.K. ${ }^{1,2}$ 